\title{
Reputation in the fifteenth century credit market; some tales from the ecclesiastical courts of York
}

DOI:

10.1080/14780038.2018.1492790

\section{Document Version}

Accepted author manuscript

Link to publication record in Manchester Research Explorer

\section{Citation for published version (APA):}

Robb, H. (2018). Reputation in the fifteenth century credit market; some tales from the ecclesiastical courts of York. Cultural and Social History, 1-17. https://doi.org/10.1080/14780038.2018.1492790

\section{Published in:}

Cultural and Social History

\section{Citing this paper}

Please note that where the full-text provided on Manchester Research Explorer is the Author Accepted Manuscript or Proof version this may differ from the final Published version. If citing, it is advised that you check and use the publisher's definitive version.

\section{General rights}

Copyright and moral rights for the publications made accessible in the Research Explorer are retained by the authors and/or other copyright owners and it is a condition of accessing publications that users recognise and abide by the legal requirements associated with these rights.

\section{Takedown policy}

If you believe that this document breaches copyright please refer to the University of Manchester's Takedown Procedures [http://man.ac.uk/04Y6Bo] or contact uml.scholarlycommunications@manchester.ac.uk providing relevant details, so we can investigate your claim.

\section{OPEN ACCESS}


Reputation in the fifteenth century credit market; some tales from Yorkshire

The early modern credit market has been identified as the melting pot where the moral economy, a free market subject to the 'shared rules, norms and assumptions that define 'right' behaviour', was best played out providing a stage on which reputation was judged and conferred. ${ }^{1}$ Yet how these key concepts of reputation and trust were understood and practiced in the late medieval market has remained elusive and the Reformation as an abstract watershed between the two epochs strengthened as historiographical trends towards a cultural history of money and credit proliferate in studies on post Reformation society. ${ }^{2}$

This article explores the language used to defend reputation in instances of defamation presented before the ecclesiastical courts of the Archbishopric of York in the latter part of the medieval period. Finding a circulating language of trust and household credibility, the argument concludes that the commodification of reputation was not a phenomenon brought about by the Reformation but a currency intrinsic to a market embedded in informal institutions, social norms and cultural dictates. ${ }^{3}$

Since the work of M M Postan in the 1920s exploring the prevalence of mercantile credit networks and the sophisticated instruments of exchange that bolstered long distance trade, studies on credit at all levels of society have proliferated in medieval history. ${ }^{4}$ Yet despite growing interest in rural credit and small scale credit agreements in studies of late medieval England, discussions of credit and debt as social indices along which societal norms and ideals of community and market ethics may be traced have yet to be advanced in late medieval English historiography. ${ }^{5}$ Instead the works of Elaine Clark, Phillipp Schofield and Christopher Briggs have focused on the nature of credit, be it exigent or investment, and the hierarchies forged in the borrowing and lending patterns of manorial court rolls. ${ }^{6}$ For the North of England, in particular the communities of Yorkshire, very 
little is known of the types of credit extended and those behavioural norms and the social conducts that shaped economic transactions in day to day market exchanges despite there existing a vibrant debate about the economic downturn of the city and abandonment of civic administration. ${ }^{7}$ Writings on credit in the early modern period, most notably those of Craig Muldrew, have explored the notion of credit as a means of conveying the value of an individual not just monetarily but socially, including reputation and characteristics of trustworthiness. As networks of borrowing became wider and ever more precarious a reputation for honesty and good neighborliness entered the economy as a circulating currency producing a market in which 'reputation was no less a part of someone's 'value' than any monetary calculation of their alienable property. ${ }^{8}$ The persistence of social relationships and interpersonal networks in economic markets has become a central feature of early modern and modern social histories of credit and debt. Both Margot C. Finn in The Character of Credit and Deborah Valerize in The Social Life of Money have incorporated sociological and anthropological understandings of the gift economy in their histories of monetary exchange in the eighteenth century English consumer revolution, finding in consumer transactions the persistence of ritual associated with pre-monetary gift economies. ${ }^{9}$ For the history of the sixteenth and seventeenth centuries 'credit' is imbued with all its social caveats producing literature Phillipp Schofield regards as 'one or two degrees removed from the direct study of indebtedness', the forms of credit and the instruments and institutions established to facilitate its exchange which have remained the predominate focus of medieval literature..$^{10}$

This divergence in historiographical approaches does not simply mark a departure in language and focus but has in itself produced a narrative in which the fifteenth century remains an age of transition. The claims of Muldrew that the sixteenth century witnessed the commodification of reputation in a social environment in which universal medieval 
Christian values of 'love and ritual, and natural sociability' no longer formed the foundation of community have gone unchallenged by medieval scholars despite J. L. Bolton in the Howard Linear Lectures expressing a suspicion that the sociable functions of the credit market identified by Muldrew as new and significant developments for the sixteenth and seventeenth centuries were well established, particularly in small scale credit agreements, as early as the thirteenth. ${ }^{11}$

The research questions within this article are driven by this disjuncture in historiographical focus, taking questions about the sociability of credit asked of early modern history and applying them to the late medieval period. Focused on the cause papers of the ecclesiastical courts from the Archbishopric of York this article explores the presentation of defamation in the courts in instances of pleas of defamation and theft and debt, the language used to describe and defend reputation and the implications of reputation in the marketplace. In doing so it explores how credit functioned in the fifteenth century market and questions whether understandings of credit, indebtedness and trustworthiness fundamentally changed in the transition to the early modern epoch. The article first explores the prosecution process at York and the legal justification for the presentation of defamation in the ecclesiastical courts, identifying a relationship between the legal formulae and the informal codes of behaviour that regulated market ethics. The second section of the article explores in detail some of those instances of defamation and theft in which the trustworthiness of the defendant was thrown into disrepute. The language used in depositions and witness statements all point to a currency of trust and a market in which reputation was considered a valuable commodity. The close of the discussion considers the wider implications that can be extrapolated from this localized study of York. It considers those debates of Douglas North, Avner Greif and Sheilagh Ogilvie on the emergence of economic institutions to formally regulate markets and contracts built on informal credit agreements. ${ }^{12}$ Though 
focused on seemingly trivial sums of money and economic actions insignificant to the national and international mercantile networks of the late medieval period the nature of defamation and debt discussed here and the processes by which they were prosecuted is essential to forge an understanding of a period in which reputation based personal exchange coexisted with credit contracts enforced by formal law-based institutions. In positing a social history of credit that discusses the language of reputation the argument here goes someway to forging that 'social indices' against which the cultural embededness of the late medieval market might be understood. The stories of warring neighbours and reputation built and destroyed are unique to the cause papers of the ecclesiastical courts. They offer a detailed insight into the informal structures and moral codes that shaped credit agreements that is not possible to glean in the records of the manorial courts. If the studies of Schofield and Briggs point to a credit market more attune to investment and profit than previously considered, then these stories at York attest to the continuance of interpersonal trust in credit transactions, showing that the reputation based economy was not antithetical to impersonal exchange or profit driven investment enforced by formal means of law and written contract.

\section{Defamation in the Ecclesiastical Courts of York}

The cause papers on which this article is based are taken from the ecclesiastical courts of the archbishopric of York deposited in the Borthwick Institute. The bishops court at York has left a substantial series of legal suits with over six hundred cases catalogued at the Borthwick Institute for the period 1300-1500. Although these cases represent only a fraction of the instances listed in the act books it is a body of material unparalleled for this period in other ecclesiastical courts. ${ }^{13}$ The court, held at York minster within the city walls, operated from 1300-1858 and heard cases from across the diocese, an area which encompassed all three ridings within Yorkshire up until the demise of the ecclesiastical court in the mid nineteenth century. Although a clear hierarchy amongst the various ecclesiastical courts within the jurisdiction of York 
archbishopric is difficult to discern, the courts can be divided into two branches; the Consistory Courts operated by the Bishop, and the lesser ecclesiastical courts, the Peculiars, held within the 134 parishes surrounding York. The Consistory Courts presided over by the Bishop, the Court of Arches, Court of Audience and the Prerogative Court, were held within York Minster in the north transept of the cathedral whilst the Peculiars and Prebendal courts were held in designated parish churches throughout the outlying areas of the York diocese. Both courts operated on separate circuits, producing two different sets of court act books with those pertaining to the Peculiar jurisdiction held by York Minster and those of the Consistory Court held by the Borthwick Institute. Those instances heard before the Bishops court at the York and the pertaining he cause papers have been collated in one holding at the Borthwick Institute of York forming a collection of papers for the Curia Ebor. The papers rarely exist in their entirety for an individual cause heard before the church courts. Nor do they reflect the level of activity in the ecclesiastical courts. The act books of the Consistory Court range in date from 1416 to 1508 yet record piecemeal ranges accounting for a total of just eighteen years for the fifteenth century. Over the course of the fifteenth century just 300 cases retain corresponding court material yet an index of the act books suggests a figure significantly higher than this was processed through the courts over the course of the eighteen years for which they account. Much like the court act books produced by the Sheriff's court, the entries in the ecclesiastical court books are often short and provide little information regarding the precise details of the case. The majority of entries appear to relate to the preliminary stages of the hearing, recording the names of the plaintiff and defendant and the fixed date for the cause to be heard in court, without any reference to the nature of the case. Though cases can be traced through the act books, entries appear only as a reference to the business conducted on that particular day and provide more detailed information regarding the advocates, proctors and lawyers involved than they do the intricacies of the case or the stage to which the case had progressed. Although the act books alone do not give any indication of the true frequency of pleas of debt as instances ran over multiple court sessions, they do point to the popularity of the ecclesiastical legal system in York. The accompanying cause papers, though only a slim percentage of the number of cases processed in the courts, provide the intricate details surrounding the sociable functions of late medieval credit and debt. Cases concerning defamation, debt, property, probate and marriage were all brought before the church court at York. The vast array of cases heard offer a unique insight into the social, economic and cultural 
development of the city and the surrounding region in the North of England. Despite this the collection remains under-used. ${ }^{14}$ The study here focuses on those instances of defamation associated with theft and debt. In these cases the reputation of creditors and debtors was hotly contested and the witness statements attest to the social and economic significance of a good character.

The instances discussed here all attest to the commodification of reputation and a circulating language conflating value and trust. They cases are representative of those that survive in the cause papers at York over the course of the fifteenth century. They are a full sample of those cases of defamation presented alongside accusations of crimes of a secular nature relating to market practices, theft and false dealings. They are however, just a fraction of those cases we know to be presented before the church court in York. What's more they are only those cases that had been contested in an appeal at the bishopric or the few that came directly under the jurisdiction of the minster. The prebendal courts under the jurisdiction of York minster show instances of defamation formed part of the regular business of the church courts. The prebendal courts of the collegiate church of SS. Peter and Wilfrid at Ripon shows that 116 cases of debt were processed in the latter half of the fifteenth century and 16 instances of defamation of character. These smaller church courts were the first stage of litigation yet do not hold cause papers pertaining to the case. The documents are an excellent source of quantitative data yet to be fully catalogued. They can not however, illuminate the social and economic upheavals caused by a suit of slander in the extent of the detail provided in the cause papers of York minster. The market of the late medieval period was culturally embedded. There is an important distinction to be made however, the economic practices of the credit market of the fifteenth century were informed by and not subordinate to informal institutions that is 'the humanly devised constraints that shape human interaction'. ${ }^{15}$ The exploration of the cause papers within this article points to a dialectical relationship between the legal infrastructure and informal codes of behaviour. 
We can see a moralizing language describing character and reputation emerging within these documents from the very legal system that constructed and codified the day to day practices of the marketplace. The language used to defend reputation within these cases is more than legal formulae. It is a product of the vocabulary used in the market to attest to good character and creditworthiness of borrower and lender whilst itself framing and structuring credit contracts. As such the cause papers here offer a previously unexplored and unique insight into those social expectations of trust and neighborliness that governed, and were produced within, the credit market in fifteenth century York.

Despite uncertain legal grounds defamation, certainly by the sixteenth century, formed the staple of legal hearings in church courts throughout England. ${ }^{16}$ The expansion of the thirteenth century Gregorian decretals, designed to protect the reputation of clergy against false accusations of criminal activity, to include the laity in the English ecclesiastical legal system is recorded in codes read aloud to congregations towards the close of the fourteenth century, threatening excommunication to anyone who defamed their neighbour by means of false accusation of a crime. The coupling of defamation with false accusations of criminal behaviour placed emphasis on the intent behind the slanderous words spoken by the defendant. Defamation could only occur in the church courts where the accusation was false and the words spoken with malice and intent to denigrate the good character and reputation of the plaintiff. In a section of a household handbook of the late fifteenth century entitled 'Disturbers of the King's Peace' the author reflected on the legal code under which defamation might appear in the courts;

And alle thou arn acursyd that for malyce, or wynnyn, or favour, or any other cause, dyffamyn or slaunderyn ony persone, \& aperyn his name among gode men \& worschipfull, there he was not defamyd be-forn, \& for that slaundre he is put 
to his purgacyoun. ${ }^{17}$

The 'malyce' behind any slanderous words or the false gain to be had in spreading rumours defined defamation cases in the English church courts making it routine for witnesses called to a case to attest to the good character of the plaintiff and to record the negative impact of the defamatory words on the individual's reputation.

By the mid fifteenth century accusations of defamation expanded to include cases beyond the false accusation of criminal activity to include all defamatory and malicious words, recognising the lawful interest of an individual to protect their character in the courts. The cause papers at York reflect this trend with defamation by slander against an individual's reputation and by false accusation of a crime, such as theft, occurring concurrently in the records from the mid fifteenth century. The first cause papers at York detailing cases of defamation as a defence of reputation highlight the defining features of the legal basis on which defamation was brought to the church courts. In 1465 in a case of sexual slander Margaret Roberts sought to defend her reputation having been accused of being a 'burning hore' by her neighbour and fellow trader Walter Gray. ${ }^{18}$ Much like the cases of the later seventeenth century, when slander had become the primary business of the church courts, particular emphasis was placed on the malicious intent behind the words spoken and the public nature of the accusation. Walter Gray and Margaret Roberts had both been stood in the doorways of their shops on Fossgate street in York exchanging words across the busy shopping street when Walter Gray called out and 'hurled' the defamatory words against Margaret Roberts. The public nature of the accusation is central to the case. The multiple witnesses to the case, John and Robert Lonsedale, and Elizabeth and John Cook, and the public nature of the high street, made the accusation widely known. Elizabeth Cooke, witness and friend to Margaret Roberts, claimed that the 'status and reputation of the aforementioned Margaret perished and 
projected no good and grave punishment on her good fame causing multiple damage and immense embarrassment to her character'. Emphasis is also placed on how the words were spoken. Walter Gray not only 'hurled' the words towards Margaret Roberts but did so 'in an intelligible voice' and with a 'clear tongue'. ${ }^{19}$ The accusation was clearly audible to all those present on the busy shop fronts of Fossgate street. This case of sexual slander highlights the central features which defined instances of defamation from the fifteenth century and into the sixteenth and seventeenth centuries. The intent of the defendant to defame the plaintiff and the malicious nature of the words, along with the manner and place in which they were spoken, such as an angry or impassioned public denunciation, became the legally constitutive language of defamation in the ecclesiastical courts in the late medieval period. ${ }^{20}$

Although the language of defamation cases is couched in the formulaic legal terminology that defined defamation in the courts, the 'malicious' nature of the words 'publicly shouted' and the 'great embarrassment' caused to the character of the plaintiff, these legally constitutive elements of defamation arose from the societal norms and regional habits that determined neighbourly relations. Bound has identified in the cause papers the language of anger which allude 'to the verbal, gestural and spatial negotiation through which 'anger' was structured and performed in the context of everyday social practice. ${ }^{21}$ The use of words such as 'malicious' and 'hateful' when describing defamation and the description of the public setting of the proclamation in witness statements all point to the tensions between neighbours where reputation was fragile and hotly contested. The emotions of anger, though legally constitutive for the presentation of defamation before ecclesiastical authorities, were located 'within socially and collectively recognizable behavioural codes'. ${ }^{22}$ Hatred as a social institution in the works of Daniel Lord Smail did as much to confirm neighbourly relations as it did to disrupt. Attacks on reputation in public spaces called upon neighbours to support one another both at the 
time of the accusation and later in the court process as witnesses to the instance and to the character of the plaintiff. ${ }^{23}$ In 1464 Ellen Thompson stood accused of having maliciously spread defamatory words against John Douce accusing him of stealing from the grain store in the village of Newton. According to one witness, Richard Thruxundale, the defamatory words had been spoken following an altercation in the open courtyard between the home of the plaintiff John Douce and the second witness to the case, John Stockdale. The defamation, though public in its nature, was in a space regulated by Douce and his neighbour. Drawing on support from neighbours and friends John Douce attested to his own good reputation and character against Ellen Thompson, a character 'of notorious ill repute', by demonstrating his credibility amongst neighbours who supported his claims of defamation. ${ }^{24}$ Neighbours in the village of Marr were so convinced of the good reputation of John Heutt in an instance of defamation in 1469 that when bailiffs attended his home to impeach him and incarcerate him in the castle of York they 'faithfully promised and swore on the hand of John Spooner', Huett's witness, that he would attend the castle and prove in person that Huett was innocent of the charges levied against him. ${ }^{25}$ In this instance despite the circulation of summons about Peaseholme in the center of York, in the house of the court chaplain and the castle of York, John Huett had refused to attend court but had in the process mustered the support of his neighbours. As an informal institution that regulated behaviour hatred had the ability to affirm neighbourly relations, 'social hatreds were useful for testing and displaying one's ability to recruit kin, friends, and dependents'. ${ }^{26}$ The instances of defamation within the church courts at York evidence how individuals negotiated not only the legal system but their relations with their neighbours in a bid to defend that most precious commodity, their reputation, in the public spaces of the medieval marketplace. The sample of cases discussed below demonstrate the significance of a good reputation and displays of trustworthiness to an individual's continuation in not 
only the social but also economic sphere of the late medieval economy.

'By his good faith and honest reputation', defending reputation in the credit market

In 1434 William Barton brought an instance of defamation and theft against John Partryngton to defend his reputation after Partryngton accused him of reneging on the terms of a credit agreement. William Barton and John Partryngton had previously entered a written bond to secure the extension of credit before a group of jurors comprising of their business associates. The deal had been sealed with the exchange of a surety of three pounds, thirteen shillings and four pence safely stored in a box and held in the custody of John Partryngton and his wife. Partyryngton went on to publicly accuse Barton of seizing the box containing the surety from his wife and breaching the terms of the agreement. Both men were skinners in the city of York. The jurors called to witness the bond were likewise skinners and merchants in the city. The agreement between the two parties had been sworn in the presence of their business and social networks so when John Partryngton publicly accused William Barton of breaking the terms of their contract William Barton's reputation as a trustworthy business partner was compromised. William Scheffield, witness to both the signing of the bond and the instance of defamation, recalled how the 'angry and malicious' words spoken by John Partryngton had caused immense embarrassment and damage to the previously 'unviolated and esteemed reputation' of William Barton. ${ }^{27}$ We know from other instances of defamation and debt that the denigration of the character of a business partner could have real monetary implications. In 1435 James Aston brought a case of defamation and debt against Adam Beckwith. Beckwith owed money to his creditor, Aston, having deferred payments for the rental of a tenement in the village of Ripley. The defamation arouse when Beckwith claims he faithfully made the payment of nine marks and four 
pence to Aston's steward and that the payment had not been recognised, bringing Aston's reputation as an honest and trustworthy associate into disrepair. Robert Selby, witness to the defamation strongly believed that Beckwith had purposefully 'made a commotion in order to defer the promised terms to which he had committed' by means of damaging the 'esteemed public reputation' of Aston. ${ }^{28}$ The false accusation that his payment had gone unrecognised sought to purposefully discredit Aston as a lender so that the terms of their previous credit agreement may be brought into question and Beckwith relieved of his obligation to make the repayment. Reputation was conferred before business associates and when contested had real monetary implications for the business dealings of those involved. It was a commodity with a tangible value worth defending before the courts.

In the Easter of 1431 John Marshall, Thomas Clerk, and John Bell, from the village of Sutton upon Derwent, along with Robert Basse stood on the pavement in Grapelane in the city of York bidding for the skilled labour of William Eggleton, a cordwainer. During the negotiations Thomas Clerk accused John Marshall of dealing in false gold outlawed be royal proclamation, publicly declaring that John Marshall deceitfully used false and counterfeit coins when buying and selling malt with merchants throughout York to gain unlawful profits. ${ }^{29}$ The use of counterfeit coins, though widespread in periods of low minting outputs, was charged as treason. In 1484 John Stafford was accused of minting counterfeit coins and using them in the city of York to the 'grete disseit and hurt of the kinges people'. He was held in prison and became the subject of a protracted negotiation and 'punyshed after his demerites'. ${ }^{30}$ The accusation of counterfeiting coins in order to gain unlawful profits was a serious one. As Thomas Clerk levelled these accusations in the street John Marshall grew increasingly angry. John Bell, witness to the defamation, recalled how Thomas Clerk addressed the increasingly 'somber and dark face' of John Marshall as he continued to publicly declare the 
fraudulent activities. ${ }^{31}$ Following the accusations in the centre of York the business his character and tarnished his reputation to the extent that no men of good character from the city of York, the village of Sutton upon Derwent or any other neighbouring village, having heard of the case, would enter business with John Marshall. The social and economic isolation of Marshall following the case mirrors that of Margaret Roberts who, after being defamed by her neighbour, was socially ostracised. Much like instances of defamation and character it is the public nature of the denigration that caused the greatest damage. In 1490 Richard Iveson stood before the congregation in the church at Scarborough after the celebration of the feast of saint Mark the evangelist to denounce the business activities of John Harrison. Before the congregation Iveson accused Harrison of using 'nefarious' practices to defraud him of his money claiming he was unfit to deal with money having fraudulently retained goods held on his behalf shouting that John Harrison 'is a false harlot for he has my goodes and said he is robbed'. ${ }^{32}$ It was evidently not the first time the accusation had been levelled against John Harrison as witness statements refer to a prior process of compurgation as Harrison called on friends and associates to attest to his good character in defence of his reputation. The public denunciation of Harrison's character at church in spite of a successful defence of his character previously, compelled Harrison to process a claim of defamation before the bishop's court.

The same language used to defend reputation in these instances of defamation and theft are paralleled in those instances of breach of faith where contracts for the repayment of debts were contested. Oral contracts were sworn on the 'good faith and character' of the borrower. Witnesses to the transaction, those 'faithful and worthy people', were drawn into the contract attesting to the character of those involved and validating the agreement. Borrowers were bound 'to fulfill the promise based on trust to repay' and business negotiations hung on the language of trust and honesty. ${ }^{33}$ In 1484 
Richard Reade struck up a business deal with Thomas Wright to establish a stall at the local market at Leonard's Landing in York. When finalising the terms of the agreement he had given a 'faithful and public pledge' to deliver the grain to the attorney Thomas Williamson, in order 'to honestly fulfill the deed' between himself and his business partner. ${ }^{34}$ A good name was central to securing financial deals. In 1469 John Huett entered a rental agreement with John Wyntryngham on the condition of the field yielding a successful crop. When the crop failed John Huett offered a secutiry 'on the promise of his name' to pay the outstanding 3 pounds and 15 shillings and 1 pence. ${ }^{35}$ The language of trust and good character permeated the oral contracts of the day to day borrowing and lending in and around the city of York with sureties being offered against the good reputation of an individual. It is a language found in the household manuals of the late medieval period. The manner book, 'The Little Children's Little Book', advised on the importance of reputation for buying and selling on credit in the market warning of judgment for those who were deceitful in market transactions; 'Use no swearing or falsehood in buying or selling, else shall be you shamed at the last. ${ }^{36}$ The breaking of an oath in a contract was likewise considered a sin. The text Jacob's Well condemned untruthful promises listing the breach of an oath as one of the seven leaves on the branch of forswearing that precede a sin, 'for he that hatyth thru 3 truthe, \& fulfylleth it nyt, is for-sworn, for truthe vnkept \& othe brokyn is all on. ${ }^{37}$ To gain profits unlawfully and unjustly was widely condemned. Sermons denouncing the sin of covetousness warned that buyers and sellers, and borrowers and lenders engaging in transactions with unjust usurious charges were accursed. Honesty and reputation were paramount to successful credit negotiations and the importance of the reputation of the household as well as the individual was widely preached.

Medieval markets were governed by a myriad of regulation both formal and informal. The institutional framework of the late medieval period, that is 'the humanly 
devised constraints that shape human interaction', extends to the societal 'conventions and codes of behavior' that infiltrated economic activity. ${ }^{38}$ Formal regulations imposed on traders were informed by those informal institutions, cultural attitudes and understandings of money, profit and prices. Rather than presenting a medieval moral economy in which profit and individual gain were antithetical to concurrent religious teachings on avarice and usury, James Davis has argued that moral justification and moralising language informed commercial regulations without excluding motivations for profit by considering the communal good. ${ }^{39}$ The cultural embededness of exchange in the medieval market place was thus not prohibitive to economic acquisitiveness nor subordinate to religious codes of behaviour. Indeed the very same moral code that hung about the reputation of the individual regulated behaviour in the medieval market as it did in the early modern.

The terminology used by both proctors and witnesses to the instances of defamation referred to the public notoriety of the individual and the significance of their household reputation to their interactions within the social and economic community. In an appeal case taken from 1455 both the defendant and plaintiff sought rigorously to protect their name in a case of false accusation of theft. The plaintiff, William Turpin, who was accused by William Yerwith of having stolen five gold nobles and two silver sets, sought to defend his own reputation, his proctor claiming he 'was and is a man of good fame and faith and honest living' having maintained a household with 'such an excellent prominent notoriety and public reputation'. ${ }^{40}$ rior to the 'false and malicious' defamation publicly spoken by William Yerwith, William Turpin's public image was uninjured and one of 'good fame and grave power'. This language is echoed in the witness statement of Thomas Rowley who claimed that by his own knowledge that both William Turpin and his wife had 'an honest way of life' and that 'by his good faith and his honest status' William Turpin maintained a 'faithful home and reputation'. ${ }^{41}$ The 
importance of household reputation was similarly defended in the instance of sexual slander between Margaret Roberts and Walter Gray. Andreas KynKorne, witness to the defamation, claimed that he had known Margaret Roberts 'going back years' and that he had always known her to have maintained 'a home and reputation as a woman of good fame, reputation and honest conversation'. ${ }^{42}$ The reputation of an individual was clearly central to the social interactions of late medieval society, evidenced not only in the readiness of individuals to legally prosecute but in the impact recorded in witness statements. When rumours spread following the defamation of Margaret Roberts where Walter Gray had publicly declared she was a 'burning hore' in the street of her home and business, Margaret appears to have been ostracized from her community with witnesses claiming that the damage to her character and subsequent embarrassment was so great that no men or women in the city of York, having heard the rumours, would engage with her in conversation. ${ }^{44}$

Unlike the secular courts which swore in juries to deliver judgement and sentence, the ecclesiastical courts operated a legal system based on 'judicial evaluation of evidence produced by the parties'. ${ }^{43}$ The accounts of witnesses were paramount to the functioning of the ecclesiastical legal system producing a legal framework which placed emphasis on what was publicly witnessed and commonly held to be the truth. Those contracts at the close of the medieval period that bolstered the day to day commerce of the marketplace were spoken. They were legitimized by onlookers who were witness to the agreement. Oaths were sworn and conferred in gestures and verbal promises. A handshake, the sharing of a meal and wine or the symbolic transfer of turf to confer a sale of land all confirmed and legalized the oral agreement. In a legal and civic culture that lacked the predominate role of public notary to record credit agreements and contracts it is these gestures and spoken oaths witnesses recall in the court proceedings that legalized and formalized the credit agreement. The importance of the orality of the 
contract was also reflected in the legal documents. Summons to court were displayed in civic and ecclesiastical buildings, proclaimed in market centres and read before congregations. ${ }^{45}$ The materiality of these documents and the impression they caused on both the physical and auditory landscape is mirrored in the culture of credit agreements, confirmed in physical ritual and verbal promises. Both the legal culture and the culture of credit and contract were founded in public spaces. Reputation, that projected version of the self as a trustworthy and virtuous member of an honest household and wider social network, was a key commodity in successfully negotiating the economic landscape of late medieval England both in the marketplace and the courts. ${ }^{46}$

Both the court procedure itself and the marketplace thus offered a public forum in which these reputations could be contested, conferred and discredited. By the fifteenth century the ecclesiastical court at York expanded from the single curia Ebor, established in the thirteenth century, to include two additional courts, the consistory court and the chancery court. ${ }^{47}$ Though the medieval consistory court at York no longer exists in its physical entirety, the cathedral in the neighboring diocese of Chester still retains a consistory court which has been dated to the early sixteenth century. The set up features two stands in which witnesses, defendants and plaintiffs could be called and prosecution proctors stand to posit cases to the judge, a central seat for the judge, a large square table in the center around which are fixed benches and a single raised seat for an apparitor to record proceedings from a vantage point with a view of the entire semblance. The court benches form a single independent wooden unit around which space is left for additional benches and chairs for public onlookers. Though positioned at the back of the cathedral the large steps outside the court, where individuals queued, and the seating around the edge of the court bench, highlight the very public nature of the private court case in the ecclesiastical legal system. In the fifteenth century ballad, 'Fryar and Boye', which centers around a dispute between a boy and a friar in an ecclesiastical 
court, the busy court is described as a center of commotion where 'other people a great pace flockt to the court to heare each case'. ${ }^{48}$ The ballad also infers an interaction between those stood in court and the surrounding audience. After the stepmother accuses the boy of witchcraft she is met with public humiliation:

She lowd, the assembly laught thereatt, \& said 'her pistolls crake was flatt, the charge was all amisse. ${ }^{49}$

Fearing another such repose from the crowd she 'stood mute, \& neere a word shee spake: shame put her in such dread. ${ }^{50}$

The court process was a very public affair and threats to prosecute alone could result in an out of court settlement. Over one third of instances at court in Norwich failed to proceed beyond the initial stages of citation. The public nature of the prosecution process from citation to public arbitration and compurgation, and the final stages of prosecution in the court rooms of the Archbishopric of York provided a stage on which reputation could be won and lost. Punishments enacted by the church did not seek fiscal restitution but the restoration of broken oaths and community concord and as such focused on public penance. John Papedy, a debtor who was found guilty of breaking a promise to repay a debt over the course of three installments, was to walk before his community barefoot and with his head naked towards the church of his descendants in his village of Warter bearing a generous gift for the church in his hands. ${ }^{51}$ This ritual was to be performed for three of the Lords days. Orchestrated in the public arena before his neighbours paying more than just penance to those to whom he had broken his promise but with the ritual humiliation of a poor man in the church of his 
ancestors and before his own heirs. The punishment was designed to discredit John Papedy and his household as much as it was a display of repentance to the church and his creditor.

Contracts and credit agreements, trials at court and punishment in the church were all played out before spectators. Both legal system and credit networks were dependent upon the importance of reputation and the willingness to defend it, leading to what Smail has termed the 'consumption of justice'. Cases of defamation identified by Smail in France and those found in the cause papers at York were processed from the peripheries, from individual actors, and not imposed by central administration. ${ }^{52}$ The recourse to the courts, a formal institution, to settle instances of debt where credit was agreed and made legal in the informal codes of ritual and custom recasts the plaintiff as a consumer of justice using the court to defend and define the moral codes of their social and economic community. The propensity to prosecute despite the heavy costs involved in pursuing a case, with some instances recording fees and expenses amounting to over thirty shillings, is itself indicative of the commodification of reputation in the credit markets of medieval England..$^{53}$

\section{Conclusion: Reputation in the marketplace}

Craig Muldrew's approach to credit in early modern England has pioneered an economic history that has identified a culture of credit. His work has found that a language of trust predominated commercial transactions in the credit networks of early modern England. As networks of borrowing became wider, reputation for honesty and trustworthiness became an attribute of wealth outwardly displayed in good neighborliness, hospitality and

charity. ${ }^{54}$ Precisely because these credit networks were based on informal agreements and societal conventions of trustworthiness the credit market and the conflicts defending 
reputation forged bonds which held communities together as neighbours, friends and kin were called upon in the legal process. ${ }^{55}$ In locating credit networks based on reciprocal bonds of trust in the seventeenth century Muldrew has argued for greater continuity from the medieval to the early modern. Despite widening credit networks and increasing commercialization in a monetized economy, transactions in the seventeenth century continued to be framed by those rituals of a pre-monetary society dictated by bonds of reciprocity more often considered to be characteristic of the medieval economy. ${ }^{56}$ However, Muldrew argues that the expansion of long distant credit relationships forged in a complex and far reaching web of interdependency heightened fears over illiquidity and in turn contributed to a new language of credit centered around notions of trustworthiness and honesty. Concomitant with a shift in discourse that described a 'commonwealth' stressing national productivity over harmonious social and economic relations rose an understanding of market relations as 'expressions of interdependence and trust'. ${ }^{57}$ It is thus in the expansion of economic markets in the early modern period that the sociability of credit and commodification of reputation is located. Within this historiography the medieval market is restrained and economic activity subordinate to Christian ethics, medieval economic culture 'lacked the concept of the market as a selfregulating system of economic relationships. To a very considerable degree, it was hostile to the notions of untrammeled individual freedom in economic affairs and material gain as an end in itself ${ }^{58}$ The market of medieval England is too often considered rudimentary and inward looking in those histories that identify the Reformation as that watershed towards unabashed economic acquisitiveness.

The language used to describe reputation in the instances of defamation and theft within this article does not appear all that different to the language used to defend reputations in the defamation litigation of the early modern period. Those cases at York from the period J. A. Sharpe has identified as prolific for defamation suits, 1560-1730, 
show a marked similarity in the language used to describe reputation. ${ }^{59}$ Both depositions and witness statements draw on the same language to attest to the honest living of the plaintiff. The same claims to 'honest and good fame', 'public reputation of notoriety' and an 'honest and uninjured life', punctuate the depositions of the seventeenth century. ${ }^{60}$ Prosecution proctors utilised this language in the articles of the deposition to attest to the good reputation of the plaintiff prior to the instance of defamation. It is something affirmed in witness statements. In a case of defamation of character in 1694 witnesses claimed that the 'good name, reputation and credit' of the plaintiff Thomas Marriott was 'lessened' by accusations of dishonest dealings with his neighbours. ${ }^{61}$ The primary difference in the language used in defamation instances in the courts over the two periods appears in the tendency to record direct speech in it's vernacular English. The use of English certainly gives a more accessible insight into the language used to defend reputation in the early modern period and a greater understanding of the specific language utilised on a daily basis to reference reputation. The proctor defending Thomas Marriott in the case of defamation of character for instance recalled that the defamatory words spoken, 'knevee', 'cheating kneeve' and 'rascall', were all 'opprobrius' in the parish as they implied a man of 'lewd and wicked' behaviour. ${ }^{62}$ The identification of a language of trust unique to early modern credit practices is driven not by fundamental changes in attitudes towards credit and reputation but by changes in the public record and developments in the recording of cases in the court from the Latin to the vernacular.

Finding in the court records of the late fifteenth century a circulating language of trustworthiness and honesty and an engagement with the law courts that shows a desire to prosecute and defend reputation has significant implications for the modeling and understanding of the late medieval credit market. The desire to identify a sophisticated and monetized credit network in the works of Postan in the 1920s fed into the discussions of peasant economies that saw in the transition from feudalism to nascent 
capitalism the emergence of impersonal, and predominance of, fiscal exchanges that prefigured an industrial revolution. ${ }^{63}$ As a result markets based on reputation and interpersonal knowledge of an individual's creditworthiness have been considered antithetical to systems of impersonal exchange. The former, regulated by informal sanctions of rumour and slander, was considered to have operated adjunct to those formal legal based institutions, the courts both secular and ecclesiastical. In the work of Douglas North it is in the transition from the interpersonal systems of exchange founded on reputation and trust to the formal impersonal contract that legal institutions with the power to enforce terms and payments emerged. ${ }^{64}$ Yet in the cause papers of the ecclesiastical courts we see how the two intersect in fifteenth century York. Though contracts were oral and legitimized by friends and family witness to the exchange the courts were called upon to settle resulting disputes. The legal procedure itself provided a stage on which the reputation based economy might be played out, characters were attested to in processes of compurgation, neighbours and friends judged in issues of arbitration and whole communities witnessed the parade of parties before the judge in the consistory court. The coexistence of the informal and formal sanctions on credit does not differ from those mercantile relations identified by Jeremy Edwards and Sheilagh Ogilvie that utilized local community knowledge of traders to enforce formal contracts even in long distance trade in the thirteenth and fourteenth century Mediterranean. ${ }^{65}$ The 'reputation mechanism' appears to have played a role in the contracts both oral and written of merchants and peasants alike. ${ }^{66}$

The persistence of a reputation orientated society across the medieval and early modern epochs attests to the presence of those small scale and personal credit negotiations between friends, neighbours and kin. It also suggest that those moral codes that informed the expanding credit networks of seventeenth century society were likewise influencing the economy of the late medieval market. Rather than being 
restrained by prevailing Christian notions of love and charity as suggested by both

Muldrew and Wrightson the market ethics of the fifteenth century were similarly

embedded in the social and cultural norms intrinsic to a market based on interpersonal

interactions. To extrapolate the market, and particularly the credit networks within it,

from the social relationships on which it was propped is to read it out of context of the

informal institutions that governed its workings. It is only by locating these cause papers

within debates of institutions and an understanding of the legal justification behind their

appearance before the consistory court at York that we can understand the sociological

imperatives and sanctions that drove the credit market in fifteenth century northern

England.

1 James Shaw, 'Market ethics and credit practices in sixteenth-century Tuscany', Renaissance Studies, 2, (2011), p. 236.

2 The Economy of Obligation: the culture of credit and social relations of early modern England, (Basingstoke, 1998), Muldrew, Craig. 'Interpreting the market: the ethics of credit and community relations in early modern England', Social History, Vo. 18, No. 2, (May, 1993), pp. 163-183., Margot C. Finn, The Character of Credit: Personal Debt in English Culture, 1740-1914, (Cambridge, 2005). Deborah Valreize, The Social Life of Money in the English Past, (Cambridge, 2006).

${ }^{3}$ Douglas C. North, Institutions, Institutional Change and Economic Performance, (Washington, 1991), p.4.

${ }^{4}$ M. Postan. 'Credit in Medieval Trade', The Economic History Review, 2 (1928), 234-261.

5 Phillipp R. Schofield, 'Credit and debt in medieval England: Introduction', Credit and Debt in medieval England c. 1180-1350, (Oxford, 2002), p. 3.

${ }^{6}$ Elaine Clark, 'Debt Litigation in a Late Medieval Vill', Pathways to Peasantry, ed. J. A. Raftis, (Toronto, 1981,) pp. 247-249., Phillipp, R. Schofield, 'Access to Credit in the Early Fourteenth-Century English Countryside', Credit and Debt in Medieval England c. 1180-1350, ed N. J. Mayhew (Oxford, 2002), pp. 106126., Phillipp, R. Schofield, Peasant and Community in Medieval England 1200-1500, (Hampshire, 2003)., Chris Briggs, Credit and Village Society in Fourteenth-Century England, (Oxford, 2009)., Chris Briggs, 'Manor Court Procedures, Debt Litigation Levels, and Rural Credit Provision in England, c. 1290-1380', Law and History Review, Vol. 24, No. 3, 2006, pp. 519-558.

${ }^{7}$ For economy of medieval York and mercantile credit see, Sarah Reese Jones (ed), The Government of medieval York: essays in commemoration of the 1396 royal charter, (York, 1997) Pamela Nightingale, 'The rise and decline of Medieval York: A Reassessment', Past \& Present, 206, (2010), 3-42, Jennifer I. Kermode, 'Money and Credit in the Fifteenth Century: Some Lessons from Yorkshire', The Business History Review, 65, (1991), 475-501. Jennifer I. Kermode, 'Urban Decline? The Flight from Office in Late Medieval York', The Economic History Review, 35, (1982), 179-198.

${ }^{8}$ Craig Muldrew. "Hard Food for Midas': Cash and Its Social Value in Early Modern England', Past \& Present, No. 170 (2001), 78-120, p. 98.

${ }^{9}$ Margot C. Finn, The Character of Credit: Personal Debt in English Culture, 1740-1914, (Cambridge, 2005).

Deborah Valreize, The Social Life of Money in the English Past, (Cambridge, 2006).

${ }^{10}$ Schofield, 'Introduction', p.1.

${ }^{11}$ Craig Muldrew. The Economy of Obligation, p. 203. J. L. Bolton. 'Howard Linear Lecture 2009: Was There a 'Crisis of Credit' in Fifteenth-Century England?', The British Numismatic Journal, 81 (2011), 144-163.

${ }^{12}$ North, Institutions, p.4. Greif, 'Reputation and Coalitions in Medieval Trade: Evidence on the Maghribi Traders', The Journal of Economic History, 4, (1989), 857-882. Avner Greif, 'History Lessons: The Birth of Impersonal Exchange: The Community Responsibility System and Impartial Justice', Journal of Economic Perspectives, (2006), 221-236. Jeremy Edwards and Sheilagh Ogilvie, 'Contract enforcement, institutions and 
social capital: the Maghribi traders reappraised', Economic History Review, 2, (2012), 421-444.

${ }^{13}$ Bronach Kane, 'Impotence and Virginity in the late medieval Court of York', Borthwick Papers, (2008), pp. 6-7.

14 Philippa Hoskin, Simon Sandall and Emma Watson, 'The Court Records of the Diocese of York 13001858: An Under-Used Resource', Yorkshire Archaeological Journal, Vol. 83, 2011, 148-63, 149.

15 North, Institutions, p. 4.

${ }^{16}$ R. H. Helmholz, Oxford History of the Laws of England Volume I, pp. 566-567.

${ }^{17}$ Jacobs Well An Englisht Treatise on the Cleansing of Man's Conscience, trans. Dr. Arthur Brandeis, (London, 1900), p. 15.

18 CP.F. 335, defamation (sexual slander), Margaret Robert v. Walter Gray, 1465.

${ }^{19}$ CP.F. 335, defamation Robert v. Gray, 1465.

${ }^{20}$ Fay Bound, “An Angry and Malicious Mind'? Narratives of Slander at the Church Courts of York, c. 1660-c. 1760', History Workshop Journal, No. 56, (2003) 59-77.

${ }^{21}$ Bound, 'Narratives of Slander', p. 72.

22 Bound, 'Narratives of Slander', p. 73.

${ }^{23}$ Daniel Lord Smail, 'Hatred as a Social Institution in Late-Medieval Society', Speculum, 76 (2001), 90-126.

${ }^{24}$ CPF. 205, Defamation (theft), John Douce vs. Ellen Thompson, 1464.

${ }^{25}$ CP.F. 251, Breach of faith (debt), John Wintringham v. John Hewet, 03/02/1469- 28/04/1470.

${ }^{26}$ Smail, 'Hatred as a Social Institution, p. 94.

${ }^{27}$ CP. F. 332, Defamation (debt), Barton v. Partryngton, 1434.

${ }^{28}$ CP.F. 117, Defamation (debt), Aston v Beckwith, 1435.

${ }^{29}$ CP.F. 100, Defamation (fraud), John Marshall v Thomas Clark, 28/11/1431-29/11/1431.

30 'Counterfeiters Arrested 17 December 1484', The York. House Books 1461-1490 Volume I: House Books One and Two/Four, (Gloucestershire, 1991), pp. 345-347.

${ }^{31}$ CP.F. 100, Marshall v. Clark

32 CP.F. 272, Appeals, defamation (theft), Richard Iveson v. John Harrison, 20/07/1490-23/10/1490.

33 CP.F. 210, Breach of faith, Thomas Harrison v. John Papedy, 03/07/1465-14/10/1465.

${ }^{34}$ CP.F. 266, Breach of faith, Thomas Wright v. Richard Reade, 27/07/1484.

${ }^{35}$ CP. F. 251, Breach of faith, Wintringham v. Hewet.

36 'The Little Children's Little Book', The Babees' Book Medieval Manners for the Young, trans. Edith Rickert and L. J. Naylor, (Ontario, 2000), p. 12.

${ }^{37}$ Jacobs Well, pp. 153-154.

${ }^{38}$ North, Institutions, p.4.

${ }^{39}$ James Davis, Medieval Market Morality Life Law and Ethics in the English marketplace, 1200-1500, (Cambridge, 2012), pp. 410-413.

${ }^{40}$ CP. F. 193, Appeals defamation (theft), William Turpin v. William Yerwith, 09/12/1455-09/07/1456.

${ }^{41}$ CP. F. 193, Appeals, Turpin v. Yerwith.

42 CP. F. 335, Rogers v. Gray.

${ }^{44}$ R. H. Helmholz, The Oxford History of the Laws of England Volume I The Canon Law ad Ecclesiastical Jurisdiction from 597 to the 1640s, (Oxford, 2004), p. 312.

${ }^{45}$ Hoskin, Sandall and Watson, 'The Court Records of the Diocese of York', 149.

${ }^{46}$ Finn, The Character of Credit, p. 12.

47 'Background', Borthwick Institute of York, http://www.york.ac.uk/borthwick/holdings/guides/researchguides/what-are-causepapers/\#background, [last accessed 10/07/15].

48 John W. Hales and Frederick J. Furnivall, Bishop Percy's Folio Manuscript Loose and Humorous Songs.

(London, 1867) pp. 25-26.

${ }^{49}$ Hales and Furnivall, Bishop Percy's Folio, pp. 25-26.

${ }^{50}$ Hales and Furnivall, Bishop Percy's Folio, pp. 25-26.

${ }^{51}$ CP. F. 210, Harrison v. Papedy.

52 Smail, The Consumption of Justice, p. 17.

${ }^{53}$ List of fees are to be found in an appeals case of defamation and character, CP.F. 190, Appeals

(defamation, theft and character) Roger and Roger v. Baxter, 18/12/1453-01/04/1453.

${ }^{54}$ Muldrew, "Hard Food for Midas", p. 98.

${ }_{55}$ Muldrew, 'Interpreting the market', p. 169.

${ }^{56}$ Muldrew. 'Interpreting the market', p. 177.

${ }^{57}$ Keith Wrightson, Earthly Necessities Economic Lives in Early Modern Britain, 1470-1750, (London, 2002), pp. 203-204.

${ }^{58}$ Wrightson, Earthly Necessities, p. 29. 
${ }^{59}$ J. A. Sharpe, 'Defamation and Sexual Slander in Early Modern England: the Church Courts at York', Borthwick Papers No. 58, (York 1980).

${ }^{60}$ CP. H. 1410, defamation, William Ackroyd v. Alfred Ackroyd, 1619. CP. H. 1131, defamation, Thomas Hutchinson v. William Foreman, 1615.

${ }^{61}$ CP. H. 4341, Defamation (character), Thomas Marriott v. Samuel Moss, 1694.

${ }^{62}$ CP. H. 4341, Marriott v. Moss, 1694.

${ }^{63}$ See the likes of Rodney Hilton, The Transition from Feudalism to Capitalism, (London, 1978) and Karl

Polanyi, The Great Transformation, he Political and Economic Origins of Our Time, (Boston, 1944).

${ }^{64}$ North, Institutions.

${ }^{65}$ Edwards and Ogilvie, 'Contract enforcement'.

${ }^{66}$ Greif, 'History Lessons: The Birth of Impersonal Exchange'. 